Slavica Jovetić ${ }^{1}$

Jelena Purić ${ }^{2}$

University of Kragujevac,

Faculty of Economics, Kragujevac
SCIENTIFIC REVIEW ARTICLE

doi:10.5937/ekonomika1603093J

Received: Jun 06, 2016

Accepted: August 31, 2016

\title{
COMPARATIVE ANALYSIS OF FINANCIAL AND NON-FINANCIAL PERFORMANCE ELEMENTS OF JOINT-STOCK COMPANIES
}

\begin{abstract}
Abstarct
The aim of the paper is to measure concurrence between the ranking of companies listed on the Belgrade Stock Exchange (BELEX) and their financial and nonfinancial performance elements, i.e. to measure to what extent these performance elements are included in the criteria for listing shares. By employing statistical/ econometric methodology, an analysis including 10 companies from the BELEX15 index basket was conducted. The paper is organized in four consistent sections. The first one relates to the analysis of the criteria for listing of companies on the BELEX and the ranking that the company receives based on the mentioned conditions. The second section deals with the analysis of the financial performance elements of the mentioned companies, namely: EPS (Earnings per Share), P/E ratio (Price-Earnings ratio), P/B ratio (Price-to-Book ratio) and ROE (Return on Equity) of the company. In the third section of the paper, the non-financial performance elements which are included in the ISO 9004:2009 Self-Assessment Tool and considered key components of company's success are analyzed; these are: managing for the sustained success of a company; strategy and policy; resource management; processes management; monitoring, measurement, analysis and review; improvement, innovation and learning. In the fourth section of the paper a comparative analysis of the positions of surveyed companies was carried out based on the three main criteria set out in the preceding sections of the paper. Furthermore the correspondence between the mentioned criteria was measured.
\end{abstract}

Keywords: joint-stock companies (JSC), financial performance elements, nonfinancial performance elements, ISO 9004:2009, Belgrade Stock Exchange (BSE)

JEL classification: C1,C8,G11

\footnotetext{
${ }^{1}$ sjovetic@kg.ac.rs

2 puricjelena1@gmail.com
} 


\title{
УПОРЕДНА АНАЛИЗА ФИНАНСИЈСКИХ И НЕФИНАНСИЈСКИХ ПЕРФОРМАНСИ АКЦИОНАРСКИХ ДРУШТАВА
}

\begin{abstract}
Апстракт
Циљ рада да се измери сагласност између позииије предузећа на Беградској берзи (BSE) и юихових финансијских и нефинансиских перформанси, односно да се измери колико су у критеријуме за листирање акиија укључене финансијске и нефинансијске перформансе. Анализа, помоћу статистичкоеконометријске методологије, обухватила је 10 предузећа која се налазе на листи BSE у корпи индекса Белех 15. Рад се састоји од четири конзистентне ичелине. Прва се односи на анализу критеријума за листирање предузећа на листи BSEс и позицији које предузеће заузима на основутих критеријума. Други део, односи се на анализу њихових финансијских перформанси. Анализиране су следеће финансијске перформансе, односи: ЕПС (нето добитак по акцији), П /Е (иена/ нето добитак по акичји), П/Б (иена /књиговодствена вредност ) и Р?? (принос на капитал) тих предузе? а. Тре? и део рада односи се на анализу нефинансијске перформансе које представљају оцене кљу?них перформанси успеха дефинисаних у упитнику за самооиенивање предузе? а y ISO 9004:2008 и то су: руково?ење, стратегија и политика, ресурси,ОЕ (принос на капитал) тих предузећа. Трећи део рада односи се на анализу нефинансијске перформансе које представљају очене кључних перформанси успеха дефинисаних у упитнику за самооиенивање предузећа у ISO 9004:2008 и то су: руковођење, стратегија и политика, ресурси, проиеси, праћење и мерење, побољшавања, иновачије и учење. У четвртом делу рада урађена је компаративна анализа позиције предузећа на основу сва три критеријума и измерена сагласност критеријума.
\end{abstract}

Кључне речи: акционарска друштва, финансијске перформансе, нефинансијске перформансе, ISO 9004:2009, Београдска берза

\section{Introduction}

Serbia's capital market has a long tradition, therefore, it has always been interesting for analyzing potential investors. (Dugalic and Stimac, 2007) More than a century has passed since the period when BSE had an upward development trajectory in each segment. Organizational system of BSE in the last 10 years, together with its information system and skilled staff helped this stock exchange catch up with the modern trends. The companies whose stocks are traded make the very essence of the stock exchange market. New organization of the market brought about by the implementation of the new Law on Capital Market (Official Gazette RS, No. 31/2011) has contributed to filtering out the most liquid stocks; it has also brought closer to the listing those less liquid stocks by implementing systematic changes. Hence, the appropriate conclusion is that the domestic capital market is developing in positive direction and that the significant progress has been made in this area.

BSE establishes the conditions for listing of companies [1]. These conditions are set out in the BSE Rules on Listing and they are also decisive for ranking of companies in 
the domestic market. (Dugalic and Stimac, 2007) Among the most important conditions are the following: unqualified opinion on the Report on the Audit of the Annual Financial Report of the JSC, the minimum amount of issuer's capital and the condition that in a free float there is at least $25 \%$ of the total number of issued shares. The measuring of financial performance elements in this paper was performed on the basis of the relationships of certain items of the financial statements which had been approved by the auditors. Key concept in measuring the financial performance elements of companies whose shares are traded on the stock exchange is market capitalization, which is defined as the value that is obtained by multiplying the number of shares outstanding by the current price of a share. The difference between the market capitalization and the capital contributed by investors represents the market value added (MVA). The indicators of market value include: EPS (Earnings per Share), P/E (Price/Earnings ratio), P/B (Price-to-Book ratio) and ROE (Return on Equity). (Helfert, 2001; Chordia, et al., 2003, Easton, 2004). Unqualified opinion is one of the basic conditions for the listing of a company. In addition, the aforementioned indicators provide investors a clear picture concerning company's operations, given that they are calculated on the basis of financial statements certified by an auditor. (Beaver and Ryan, 2000, Danielson and Dowdell, 2001). Together with the mentioned financial performance indicators, the conditions for the listing of a company include the psychological effect that investors transfer to the market. Furthermore, the information users are forced to re-evaluate the quality of the reports issued by the independent auditors, regardless of the existence of legal and professional constraints (Malinic, 2009). What is particularly interesting is the analysis of Goodwill which is considered a very important item in business valuation and which in each report equals 0 (Ramanna and Watts, 2009). Thus, considering the domestic market, the value of the company cannot be analyzed in terms of this indicator.

BSE manages two listing segments - Prime Listing and Standard Listing (the most liquid stocks) which make the regulated market, as well as one additional segment - the Open Market (segment of the regulated market which is not listing) which has 88 shares from a total of 87 issuers. These three segments represent the exchange market, while the fourth segment is a multilateral trading platform MTP BELEX where the securities that do not fulfill the conditions for admission to one of the segments of the regulated market are traded (for more information please see: Jaksic, 2011).

Modern economics has shown that without fostering intellectual property and one's own research capacities, no company can have secure future. This is supported by the research in 2005, conducted by Hall, Jaffe and Trajtenberg, which confirmed that stocks of those companies that are innovative and have their own patents are actually more competitive on the market, i.e. according to the mentioned research stock prices of these companies outprice the stocks of other companies for about $3 \%$. The development of the balanced scorecard (BSC) resulted in a new concept whose main point is that those companies which focus only on financial assets are no longer able to sustain competitive advantage. Traditional systems of measuring the efficiency of the company were abandoned as obsolete even two decades ago. This is confirmed by an article titled "Chief Financial Officer" from 1995 which reads that $80 \%$ of large U.S. companies want to change their performance measurement systems. An efficient and effective performance measurement system allows the company to measure and monitor its performance in accordance with the defined strategy (Domanovic, 2013). Therefore, 
a significant part of the analysis is based on non-financial performance elements defined by a new international standard ISO 9004:2009.

All the features and principles of TQM (Total Quality Management, "Business Excellence," "Best Practice") were included in the last revision of ISO 9000 family of standards done by the International Organization for Standardization (ISO). Business Excellence is characterized by the following features: an integrated system of global quality (interaction between all activities, with the goal of effective and efficient use of resources); quality refers to the system /processes/products and the quality staffing; the company keeps all the documents as prescribed by the quality system; independent, external assessment, periodic internal and external audits of implemented quality system; management of quality costs; quality system is applied to non-production functions; application of statistical, engineering and management methods in all horizontal and vertical processes; continuous analysis, measurement, monitoring and improvement of the system/process/staff/ products; implementation of all principles of the Business Excellence (from leadership to continuous improvement and process approach). For more information on the advantages and disadvantages of the ISO 9000 family of standards please see: Suganthi and Samuel, 2004 Isaksson, 2006; Nelsen, et al., 2007; Brouch, 2011; Buntak, 2011; Jovetic, 2012, Dale, Wiele and Iwaarden, 2013. ISO 9000 family includes three standards, these are:

- ISO 9000 - Quality management systems QMSs (covers the basic concepts and language) - defines the fundamental terms relating to: quality, management, organization, products and processes, principles, compliance, documentation, testing, verification and quality assurance of measurement processes.

- ISO 9001 - Quality management systems QMSs (requirements) - specifies the requirements for the quality management system with an emphasis on enhancing the customer satisfaction.

- ISO 9004 - Quality management systems QMSs - managing for the sustained success of an organization through efficient and effective quality management system; better understanding of the wider environment in which companies operate through learning and appropriate application of improvements and/or innovations.

This international standard provides guidelines to organizations for achieving sustainable success in a complex, challenging and changing environment by using quality management approach (Hoyle, 2009). It requires three hard management necessities: a good management system, statistical process control and teamwork (Oakland, 2006). The basic idea, which is achieved through the application of quality principles, is the transformation of a vertical, function oriented organization to a process oriented one. The organization implies a network of processes, while transformation refers to improving the measurement of financial performance in terms of quality management where the managed performance represents the capability of the process to meet the needs of customers/interested parties. Lastly, by the application of the system approach to management the specified goals are achieved and the needs of interested parties are met in a balanced way.

The section 8.3.2 of ISO 9004 standard puts special emphasis on the key performance indicators (KPIs). The KIPs are factors that are within the control of 
the organization and are critical for its sustained success. (ISO9004) As a result of the adoption of the new business goals, a number of quantitative and qualitative and financial and non-financial indicators are required in order to obtain relevant information that is measurable, accurate and reliable, as well as usable for the implementation of corrective actions that will effectively and efficiently indicate the continuous improvement of the systems/processes.

For the purpose of surveying selected 10 companies, whose stocks are traded on the Belgrade SE, an assessment tool (i.e. a questionnaire) was used. This assessment tool is prescribed by the ISO 9004:2009 and its template is given in Annex A of the mentioned standard. The mentioned tool contains questions that companies can use in their selfassessment (self-assessment is a comprehensive and systematic review of the activities of the company and its performance in relation to its degree of maturity. (ISO9004) Questions are related to the KPIs and particular subprocesses in the enterprise/items set out in the standard. Nine questions refer to KIPs, item 4 of the standard contains four questions, item 5 includes 4 questions, item 6 has 8 questions, item 7 contains 3 questions, item 8 includes 9 questions and item 9 has 3 questions. According to the true answers given to these questions an organization can be categorized into the following levels of maturity in terms of sustainable success: level I-Basic level - informal approach, level II-Reactive approach, level III-Proactive approach, level IV-Systematic approach and level V-Best Practice. The lowest possible score is 41 points and the highest 205 points.

The main goal of the self assessment is to determine a plan of measures for improvement and/or innovation, which represents an input element for planning and prioritizing activities and/or innovations that would allow certain elements to be lifted to a higher level. Information gathered from the self-assessment can be used for: determination of past, present and future trends of systems/processes; identification of the achieved levels of quality concerning all KIPs and other performance elements; establishing measures and actions to unblock bottlenecks; producing guidelines for necessary improvements. The self-assessment stimulates benchmarking and dissemination of knowledge throughout the company (internal benchmarking), as well as comparisons with other companies (external benchmarking).

The research presented in this paper focuses on the indicators of the achieved quality levels of 10 joint-stock companies that agreed to fill out the self-assessment questionnaire and which fall in the BSE categories of the Prime Listing, the Standard Listing or the Open Market.

The aim of the paper is to assess the following by employing analysis: the position of particular company on the BSE; financial performance elements, non-financial performance elements and compliance/impact of financial and non-financial performance elements on the listing conditions; significance of the mentioned elements; measurement of the effect of mentioned performance elements on the development of the company and improvement of its position on the capital market.

General hypotheses:

- $\quad$ Null hypothesis $1\left(H_{10}\right)$ : BSE listing conditions include financial and nonfinancial performance elements.

- $\quad$ Null hypothesis $2\left(H_{20}\right)$ : There is an optimal balance between the financial and non-financial performance elements concerning the BSE listing conditions. 
Specific hypotheses:

- Null hypothesis $3\left(\boldsymbol{H}_{30}\right)$ : There is no statistically significant effect of independent variables: market capitalization, P/E, P/B, EPS and ROA on the dependent variable - volume of shares sold.

- Null hypothesis $4\left(\boldsymbol{H}_{40}\right)$ : There is no statistically significant effect of independent variables: management assessment, leadership, strategy and policy, resource management, processes, monitoring and measurement, improvement, innovation and learning on the dependent variable - overall assessment of the level of quality and maturity of the company.

- Null hypothesis $5\left(\boldsymbol{H}_{50}\right)$ : There is no statistically significant effect of nonfinancial independent variables QMS on the dependent variable -volume of shares sold.

- Null hypothesis $6\left(\boldsymbol{H}_{60}\right)$ : There is no significant correlation between the position of the companies listed on BSE and financial performance elements, also there is no correlation between the position the company listed on BSE and non-financial performance elements.

In addition to these specific null hypotheses, also other specific null hypotheses are defined in the paper, which stem from applied statistical/econometric methodologies: regression and correlation analyses (hypotheses about multicollinearity, heteroscedasticity, autocorrelation and the assumption on distribution of random error and its arithmetic mean, etc.).

\section{Research methodology}

Type of research - Empirical analysis of the position of the companies on Belgrade $\mathrm{SE}$ and their financial performance elements was carried out for those companies that agreed to fill out the ISO 9004:2009 self-assessment tool, i.e. the questionnaire. Financial statements make the primary resource for the data collection on financial performance elements, while the data on non-financial performance elements was obtained from a questionnaire filled out by the executives of the listed companies. The questionnaire was distributed to all the companies whose shares are listed, as well as to those that are on the Open Market. The survey was conducted from June to October 2013 and it consisted of two parts: Part I related to the key elements of success (KES), performance elements and the level of maturity referenced against each performance element (scores range from 1 to 5 , where 1 stands for the lowest level and 5 for the highest level). Respondents chose scores according to their self-assessment of the development of the particular KES. Part II consisted of sub-points /sub-processes, which were also used to determine the level of the company's maturity. Each element of success was broken down into several questions, thus, for example, a question about improvements and learning had three sub-questions which described in more detail the quality level achieved in particular companies.

Sample - The research was conducted on a sample of top 10 companies listed on the BSE. For the empirical analysis of the position/listing on the BSE and the achieved level of development, the following joint-stock companies were considered: NIS a.d. headquartered in Novi Sad, Komercijalna Banka a.d. headquartered in Belgrade, Metalac 
a.d. headquartered in Gornji Milanovac, Tigar a.d. headquartered in Pirot, AIK Banka a.d. headquartered in Nis, Voda Vrnjci a.d. headquartered in Vrnjačka Banja, Frikom a.d. headquartered in Belgrade, Credy Banka a.d. headquartered in Kragujevac, Čačanska Banka a.d. headquartered in Čačak and Dunav Osiguranje a.d. headquartered in Belgrade (Belgrade Stock Exchange: 2012). Executives of 3 out of 7 companies listed on the BSE filled out the questionnaire, which makes $42.86 \%$ of the total listed companies. The remaining 7 companies from the research sample are on the Open Market.

Statistical methodology - All collected data are stored in the Microsoft Excel 2007 and SPSS (Statistical Package for the Social Science for Windows, version 19) databases. For the research purposes regression and correlation analysis were applied. The collected data were statistically analyzed by using the SPSS (Statistical Package for the Social Science for Windows, version 19.0) (Pallant, 2011, Jovetić, 2007, Tabachnick $\&$ Fidell, 2007). For the purpose of determining statistical significance, a confidence level of $\alpha=0.05$ was used .

\section{Research results}

\subsection{Belgrade Stock Exchange}

The second section of the paper points out that the BELEX is similar to other stock exchanges around the world and that new organization of the market brought about by the implementation of the new Law on Capital Market (Official Gazette RS, No. 31/2011) has contributed to filtering out the most liquid shares; it has also brought closer to the listing those less liquid shares through carrying out systematic changes. In this section of the paper the Warsaw Stock Exchange (WSE) will be presented, as well as the stock exchanges of countries in the region. Furthermore, the selected indicators that determine the position of the company on the BSE will also be considered.

Compared to Warsaw SE which lists a large number of companies and their stocks, in case of the BSE this number is reduced to 8 . The main problem is the different way of privatization of large public companies which in Poland was conducted through initial public offering (IPO), while in the domestic market privatizations were carried out by means of tenders and auction sales. In Serbia, the initial proposal was that the privatizations of the largest public companies were to be done via the capital market, but it was dismissed later. By initial public offering the shares of stock in a company are sold to the general public, i.e. a company "goes public". However, prior to going public, particular company must change its ownership structure from public company to open joint-stock company. (Mumović, Pavlovic, 2010) Potential investors buy the stock of, until that moment, largely unknown companies (Certo, 2003) which are characterized by low liquidity and high risk. Such stocks are typical of emerging markets - all markets in South-Eastern Europe (SEE) and the former socialist countries, such as Poland. WSE today plays a key role in obtaining "fresh" capital from the companies and has a large number of index baskets ranging from those that include the most liquid stocks to ones characterized by the values of stocks in certain sectors. What is BELEX15 for the BSE that is WIG30 for the WSE. WIG30 includes the most liquid stocks of 30 largest companies on the WSE. Compared to BELEX15, which consists of the stocks of 8 listed and 7 companies from the Open Market 
we can say that the difference between these capitalization-weighted indexes is drastic. The reason behind this situation is that despite the banking crisis in 2009, 6 out of 18 IPOs were conducted on the WSE. There were no IPOs on BSE, although several companies wanted to acquire equity in this way (Mumović, Pavlovic, 2010).

A stock market which is in terms of its development closer to WSE is the Zagreb Stock Exchange (ZSE), where a number of public companies were privatized by means of the initial public offering. Namely, IPOs facilitated the development and continuity of the ZSE which today includes stocks of 241 companies on its Regulated Market, out of which 171 companies trade their stocks on the Regular Market, 77 on the Official Market and 7 on the Prime Market. In contrast to BELEX whose Regulated Market has 2 segments -Prime Listing and Standard Listing, ZSE's Regulated Market includes 3 segments. The main reason for this is the initial public offering in relation to BSE which one of the main conditions for any company was to offer at least $15 \%$ of its shares to the general public. It is also one of the main conditions for entering the Regular Market. The criteria for the other two segments of the Regulated Market are pretty much the same as those of BSE, only on ZSE the market capitalization for the Prime Listing is $€ 13,069,710.21$ (as of 9.12.2013.g.), while the amount required on BSE is $€ 10,000,000$. Prior to the commencement of the economic transition these two stock exchange markets were identical. It could even be said that BSE was slightly more advanced. However, today we are faced with serious development of WSE capital market and a slight deterioration of BSE. A comparative analysis of the market capitalization for all three markets will be addressed in a later part of this paper.

As already mentioned, the executives of 10 companies whose shares are traded on the Belgrade SE completed the questionnaire related to non-financial performance elements; therefore the basic performance elements related to the exchange market will be presented on the example of the company with the highest and the company with the lowest score:

1. Nis, a.d. Novi Sad - Shares of the company are admitted and traded on the Prime Listing, which means that this company meets the most stringent conditions adopted by the administrative bodies of BSE. The total number of issued shares on 15.1.2014 was $163,060,400$ and the price of the share on the same day was 938 RSD. Highest share price of 1,020 RSD was achieved in April 2013. From August 2010, i.e. the first issuance of shares, by the end of 2013, the average volume of shares sold amounted to 23,186, while the turnover amounted to 14,224,440.88 RSD.

2. Voda Vrnjci a.d. Vrnjačka Banja - Shares of the company are traded on the Open Market. The total number of issued shares on 15.1.2014 was 114, 787.00, while the price per share was 5,997 RSD. Highest price of 7,000 RSD per share was reached in January 2013. Since August 2006 by the end of 2013 the average volume (of shares sold) was 84 , while the turnover amounted to $734,636.23$ RSD.

\subsection{Regression analysis of the independent variable financial performance elements}

The regression analysis was used for identifying financial indicators that have the greatest effect on the volume of shares sold. The dependent variable is the volume of shares sold, i.e. the average value of the shares sold in the period 1.10.2012-1.10.2013. The independent variables used are values of the following: market capitalization, EPS, $\mathrm{P} / \mathrm{E}, \mathrm{P} / \mathrm{B}$ and ROE as of 01.10.2013. 
We experimented with different curves. Regression analysis showed that the given data are best fitted to linear function. Statistical significance of the regression line is high (Snedecor's F random variable is 34.086 and $p=0000$ ). Since this is a small sample, adjusted $\mathrm{R}$ squared is 76.8 and it indicates that $76.8 \%$ of the variation of the dependent variable volume of shares sold is explained by the variations of independent variable ROE. The Durbin-Watson (DW) statistic is 1.439 and is greater than the upper limit (dg $=1.32$ ), so there is no positive first-order autocorrelation; moreover DW is less than $\mathrm{d}<$ 4 -dg $<4$-dd $(1.439<2.70<3.12)$ which means that there is also no negative first-order autocorrelation. Student's t-statistics is 5.383 and is greater than the theoretical value t0.05; $9=2.2621$; and $p=0.000$. There is no multicollinearity in the model (VIF=1).

Table 1: Statistical indicators

\begin{tabular}{|c|c|c|c|c|c|c|c|c|c|c|}
\hline \multicolumn{11}{|c|}{ Model Summary, } \\
\hline \multirow[b]{2}{*}{ Model } & \multirow[b]{2}{*}{$\mathrm{R}$} & \multirow[b]{2}{*}{ R Square ${ }^{b}$} & \multirow{2}{*}{$\begin{array}{l}\text { Adjusted } \\
\text { R Square }\end{array}$} & \multirow{2}{*}{$\begin{array}{l}\text { Std. Error of } \\
\text { the Estimate }\end{array}$} & \multicolumn{5}{|c|}{ Change Statistics } & \multirow{2}{*}{$\begin{array}{l}\text { Durbin- } \\
\text { Watson }\end{array}$} \\
\hline & & & & & $\begin{array}{l}\text { R Square } \\
\text { Change }\end{array}$ & F Change & df1 & $\mathrm{df} 2$ & $\begin{array}{l}\text { Sig. F } \\
\text { Change }\end{array}$ & \\
\hline 1 &, $889^{\mathrm{a}}$ & ,791 & ,768 & 4835,81158 & ,791 & 34,086 & 1 & 10 & ,000 & 1,431 \\
\hline \multicolumn{11}{|c|}{$\begin{array}{l}\text { a. Predictors: ROE } \\
\text { b. For regression through the origin (the no-intercept model), R Square measures the proportion of the variability in the dependent variable } \\
\text { about the origin explained by regression. This CANNOT be compared to R Square for models which include an intercept. } \\
\text { c. Dependent Variable: Number of share transaction } \\
\text { d. Linear Regression through the Origin }\end{array}$} \\
\hline
\end{tabular}

Table 2: Presentation of the values of correlation coefficients and collinearity

\begin{tabular}{|c|c|c|c|c|c|c|c|c|c|}
\hline \multicolumn{9}{|c|}{ Coefficients $^{\mathrm{a}, \mathrm{b}}$} & \multirow[b]{2}{*}{$\begin{array}{c}\text { Colinearty } \\
\text { Statistics }\end{array}$} \\
\hline & & \multicolumn{2}{|c|}{$\begin{array}{l}\text { Unstandardized } \\
\text { Coefficients }\end{array}$} & \multirow{2}{*}{\begin{tabular}{|l|}
$\begin{array}{l}\text { Standardized } \\
\text { Coefficients }\end{array}$ \\
Beta \\
\end{tabular}} & \multirow[t]{2}{*}{$\mathrm{t}$} & \multirow[t]{2}{*}{ Sig. } & \multicolumn{2}{|c|}{$95,0 \%$ Confidence Interval for B } & \\
\hline & & B & Std. Error & & & & Lower Bound & Upper Bound & Tolerannce VIF \\
\hline 1 & ROE & 707,778 & 121,230 &, 889 & 5,838 &, 000 & 433,536 & 982,019 & 1 \\
\hline
\end{tabular}

The Shapiro-Wilk test for the normality of the random variable was also conducted. Since the sig. equals $0.549(>0.05)$, the null hypothesis that the random variable can be approximated by a normal distribution is confirmed. The arithmetic mean of the residual standard deviation equals zero.

Table 3: Test of normality in residuals

\begin{tabular}{|l|l|l|l|l|l|l|}
\hline \multicolumn{7}{|c|}{ Tests of Normality } \\
\hline & \multicolumn{3}{|l|}{ Kolmogorov-Smirnov } & \multicolumn{3}{l|}{ Shapiro-Wilk } \\
\cline { 2 - 7 } & Statistic & df & Sig. & Statistic & df & Sig. \\
\hline $\begin{array}{l}\text { Error for Number of share } \\
\text { transaction with ROE from } \\
\text { CURVEFIT, MOD_10 LINEAR }\end{array}$ &, 170 & 10 &, $200^{*}$ &, 940 & 10 &, 549 \\
\hline
\end{tabular}

In this case the alternative hypothesis $\mathrm{H}_{31}$ is considered. It means that the linear regression is statistically significant and that both the financial variable ROE and market 
capitalization have a statistically significant impact on trading volume. Based on selected regression type the elasticity coefficient can be calculated. By introducing substitution [2] in the formula for calculating elasticity coefficient the following result was obtained for the linear function: if the ROE changes by $1 \%$, the trading volume will increase for $94,73 \%$.

Furthermore, based on the same criteria, we can rank the companies according to the values of this indicator. Companies in which this indicator is greater than $10 \%$ have a high return on equity. In this particular case such companies are NIS a.d. Novi Sad $\boldsymbol{i}$ Metalac a.d. Gornji Milanovac.

Considering that among financial indicators, market capitalization has a statistically significant effect on dependent variable volume of shares sold (F statistic 19,$25 ; \mathrm{t}=4,865$ and $\mathrm{p}=0,001$ ), this indicator will be used for comparing BELEX with the stock exchanges in the South East Europe (SEE). The following graph shows the values of the market capitalization of the stock exchanges in the region; the position of BELEX compared to other transition countries, some of which are now the EU member states, can clearly be seen. Based on this graph, it can be concluded that the Zagreb SE is the leading stock exchange in the region concerning the observed five-year period.

Graph 1: The development of SEE stock exchanges, as measured by market capitalization

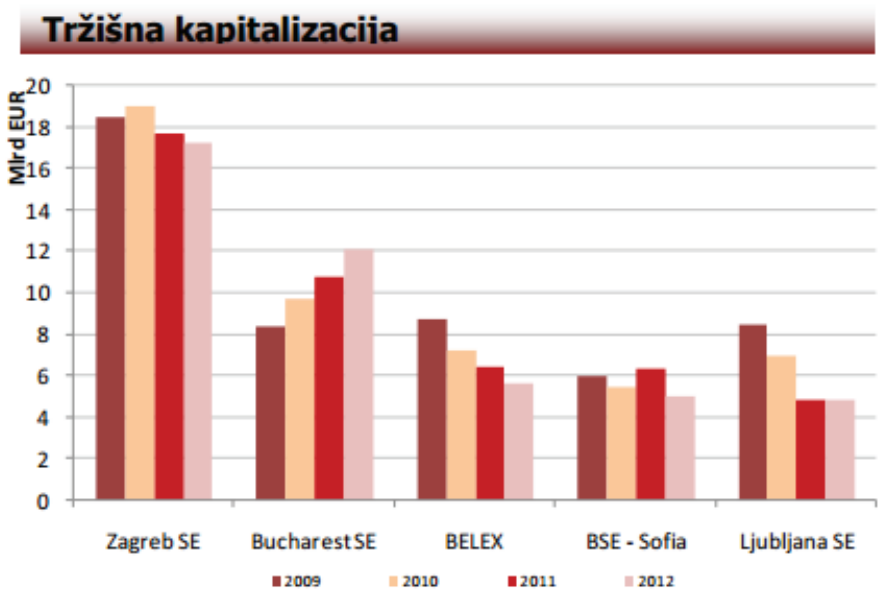

Source: Annual report for 2012, BSE

Low turnover on BSE is the result of the absence of IPO, as well as the global economic crisis which has directly affected the domestic capital market. The movements of the two most significant indexes of BSE - BELEX15 and BELEXLine best represent the situation on the market. The position of BSE in terms of other stock exchanges can accurately be determined by conducting a comparative analysis of the movements of the two mentioned BSE indexes with the movement trends of WSE indexes and SETX (South East Europe Traded Index). Graphs 6 and7 show the values of the WIG30 index [3] and SETX index [4]. A profound difference is observed not only in the index values, but also in the volume of their fluctuation. On 28.12.2012 WIG30 stood at 2582 index 
points, while on the same day BELEX15came to only 520 index points; however, also on the same day CROBEX stood at 1738 points which clearly indicates that ZSE is steadily taking the leading position in the region.

Graphs 2 and 3: Movements of BELEX15 and BelexLine observed in a three-year period
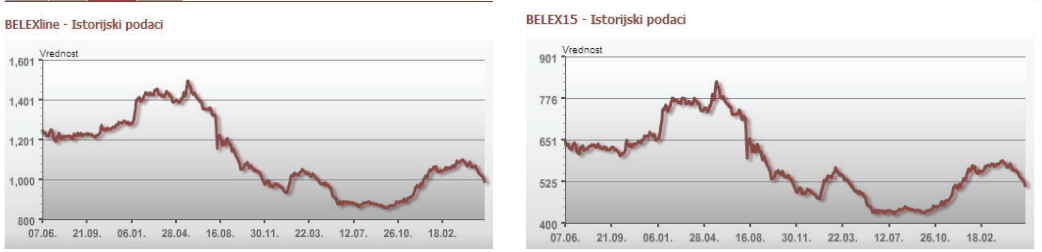

Source: BSE, available at: http://www.belex.rs/eng/ (accessed 10 November 2013)

Graphs 4: Movements of WIG30

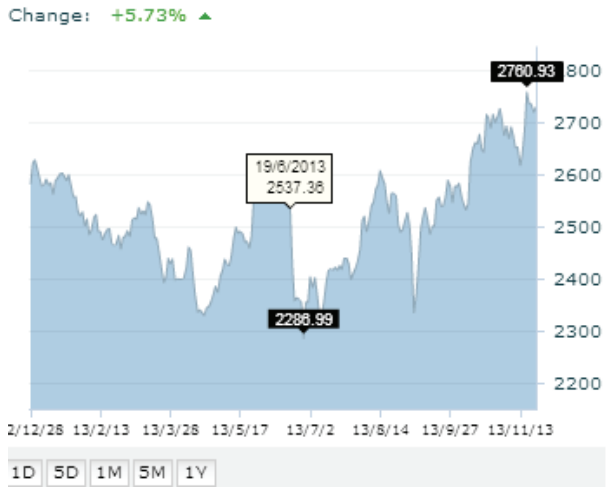

Source: WSE, available at: http://www.gpw.pl/wig30en, (accessed 10 November 2013)
Graphs 5: Movements of SETX

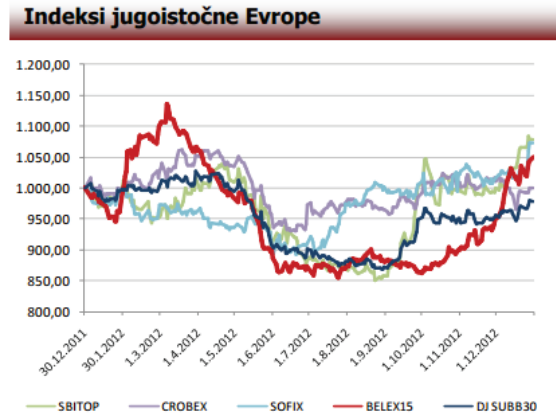

Source:ZSE, available at:

http://zse.hr/default.aspx?id=44101\&index=CROBEX

(accessed 10 November 2013)

\subsection{Regression analysis of the independent variable non-financial performance elements}

\subsubsection{The impact of independent non-financial performance on the KEU sum score}

This model identifies which of the key elements of the ISO 9004:2009 [5]standard, have the greatest effect on the dependent variable overall assessment of KPIs. Scores are determined based on the results of the questionnaires completed by persons employed in selected 10 companies, which are relevant for drawing the conclusion on the significance of non-financial performance elements that are significant for the development of particular company and its better market position. Assumptions concerning regression analysis are identical to those used in the analysis of financial indicators. 
Regression analysis showed that the data can be best approximated by logarithmic function. This was determined by comparing the values of Snedecor's F statistics. Four variables remained in the model, namely: learning, performance measurement, management and priorities for improvement. A linear function was most suitable for the data. Thus, 6 variables remained in the model; however, linear smooth hyper-surface had lower Snedecor's F statistics.

The next analysis shows the results of the linear regression. The variables which remained in the model were those relating to: learning, performance measurement, leadership approach and the manner in which the decisions on the improvement priorities are made.

The correlations between the variables in the model show that there is a relationship between the dependent variable and independent variables, since the values of Pearson correlation are higher than 0.3.

Coefficients of determination show that $99.7 \%$ of the variations of the dependent variable overall assessment of KPIs are explained by the variation of independent variables that remained in the specified model. Given the small sample used in the model, the adjusted coefficient of determination, i.e. the adjusted $\mathrm{R}$ squared, since it is a more precise indicator, was introduced and its value here is $99.4 \%$. Also, at the end of the table the value of the DW statistic is given, which is 1.053 and which is within the range of the DW critical values for $\mathrm{k}=1$ and $\mathrm{n}=9(\mathrm{dd} \mathrm{dg}=0.82=1.32)$. The test is undefined for the positive first-order autocorrelation. Since $1.053<4-0.82<4-1.32$ we can also conclude that there is no negative first-order autocorrelation.

Table 4: Illustration of statistical indicators

\begin{tabular}{|c|c|c|c|c|c|c|c|c|c|c|}
\hline \multicolumn{11}{|c|}{ Model Summary ${ }^{\mathrm{e}}$} \\
\hline \multirow[b]{2}{*}{ Model } & \multirow[b]{2}{*}{$\mathrm{R}$} & \multirow{2}{*}{$\begin{array}{l}\mathrm{R} \\
\text { Square }\end{array}$} & \multirow{2}{*}{$\begin{array}{l}\text { Adjusted } \\
\text { R Square }\end{array}$} & \multirow{2}{*}{$\begin{array}{l}\text { Std. Error } \\
\text { of the } \\
\text { Estimate }\end{array}$} & \multicolumn{5}{|c|}{ Change Statistics } & \multirow{2}{*}{$\begin{array}{l}\text { Durbin- } \\
\text { Watson }\end{array}$} \\
\hline & & & & & $\begin{array}{l}\text { R Square } \\
\text { Change }\end{array}$ & F Change & df1 & df2 & $\begin{array}{l}\text { Sig. F } \\
\text { Change }\end{array}$ & \\
\hline 1 &, $862^{\mathrm{a}}$ & ,744 & ,712 & ,05252 & ,744 & 23,218 & 1 & 8 & ,001 & \\
\hline 2 &, $946^{\mathrm{b}}$ & 894 & ,864 & 03603 & 151 & 9,997 & 1 & 7 & ,016 & \\
\hline 3 & ,994c & 988 & ,982 & ,01318 & ,093 & 46,330 & 1 & 6 & ,000 & \\
\hline 4 & $998^{\mathrm{d}}$ & ,997 & 994 & ,00756 & ,009 & 13,232 & 1 & 5 & ,015 & 1,053 \\
\hline
\end{tabular}

The significance of each independent variable is $p=0.000$, which indicates that each variable has significant statistical effect on the dependent variable. Snedecor's F statistics shows that the model, as a whole, is also statistically significant given that the values of $F$ statistic are $F=13.232$, and $t$ statistics $t 1=4,819 ; \mathrm{t} 2=3,162$ : $\mathrm{t} 3=6,807$; $\mathrm{t} 4=3,638$.

Since the variance inflation factor (VIF) is smaller than 5 for all variables in the model, there is no collinearity.

The testing for heteroscedasticity was conducted and Geisler's test was applied. Given that 4 variables remained in the model, all four of them were regressed in relation to the absolute value of the residuals. The highest Snedekor's F statistic has the variable monitoring of results achieved by implementing particular strategies; $\mathrm{F}=0.945, \mathrm{p}=$ 0.476 . Snedekor's F statistic is less than the theoretical value of $F(0.05 ; 3 ; 9)=3.86$ and $\mathrm{p}>\alpha$, which confirms that there is no heteroscedasticity. 
Empirical data are best adapted to linear regression. The hypothesis on the validity of assumption on a random variable was tested. The null hypothesis assumes that random variable can be approximated by a normal distribution. The alternative hypothesis assumes that a random variable cannot be approximated by a normal distribution. The Shapiro-Wilk test was applied (small sample). Considering that $p=0.485(>0.05)$, the assumption on the normality of the random variable distribution is verified. The arithmetic mean of the random variable is zero.

Table 5: Test of normality in residuals

\begin{tabular}{|l|r|r|r|r|r|r|}
\hline \multicolumn{1}{|c|}{ Tests of Normality } \\
\hline & \multicolumn{2}{|c|}{ Kolmogorov-Smirnov } & \multicolumn{3}{c|}{ Shapiro-Wilk } \\
\cline { 2 - 7 } & Statistic & \multicolumn{1}{c|}{ df } & \multicolumn{1}{c|}{ Sig. } & Statistic & \multicolumn{1}{c|}{ Sf } & Sig. \\
\hline $\begin{array}{l}\text { Unstandardized } \\
\text { Residual }\end{array}$ &, 179 & 10 &, $200^{*}$ &, 934 & 10 &, 485 \\
\hline
\end{tabular}

Given that all the assumptions of the regression model are fulfilled the conclusion is that the log-log regression is statistically significant and that non-financial performance elements: learning, performance measurement, leadership approach and the manner in which the decisions on the improvement priorities are made, have statistically significant effect on the dependent variable overall assessment of KPIs (alternative hypothesis $\mathrm{H}_{41}$ is confirmed).

Analysis of the data obtained from survey respondents also implied the analysis of data relating to the self-assessment of particular quality management segments.

Results of the regression analyses confirm the results obtained in terms of measuring the impact of the key elements of success, given that in both cases the same 4 companies received the highest ratings; these are: Komercijalna banka a.d. Beograd, Čačanska banka a.d. Čačak, NIS a.d. Novi Sad and Metalac a.d. Gornji Milanovac. Therefore, it is not necessary to present the results of the regression analysis. However, please note that the data are best adapted to logarithmic regression, as well as that the same variables were used for the analysis of the KPIs and regression analysis.

\subsubsection{Impact of independent non-financial performances on number of share transaction}

This analysis has aims to show a correlation between the dependent financial variable number of share transaction and the independent non-financial variables that remained in the model: management, measurement, improvement and learning . For this analysis, we used the classical two-dimensional regression model to investigate the relationship between financial and non-financial performance, which should be incorporated into the criteria for the listing of shares on the BSE. By carrying out a regression analysis between the dependent variable and the following independent variables, were obtained next results :

1. Performance measurement - Snedekor's F statistic is $\mathrm{F}=1.672$ and significance level $p$ is $p=0.232$, which indicates that the regression line is low, also the adjusted coefficient of determination (Adjusted R Square ), which is 0.173 , shows that only $17.3 \%$ of the variation of the dependent variable are explained by the variations of independently variable; 
2. Priorities for improving- Snedekor's $\mathrm{F}$ statistic is $\mathrm{F}=0.160, \mathrm{p}=0.700$, adjusted coefficient of determination is $2 \%$;

3. Learning - Snedekor's F statistic is $\mathrm{F}=0.691, \mathrm{p}=0.430$, adjusted coefficient of determination is $7.9 \%$;

4. Management - Snedekor's F statistic is $\mathrm{F}=4.906, \mathrm{p}=0.058$, which is the highest comparing other independent variables, adjusted coefficient of determination is $38 \%$.

We can conclude that, in addition to management, none of these non-financial performance has impact on number of share transaction, which will be proven by following correlation analysis. (null hypothesis $\mathrm{H}_{50}$ is confirmed)

\section{Comparative analysis of the results obtained from regression analysis}

The null hypothesis is that the general criteria for the listing of stocks on the BSE provide an adequate assessment of both financial and non-financial performance elements of the issuer. Based on the conducted regression analysis, it was determined that the financial performance element which has the greatest effect is ROE.

Top rated companies in terms of this indicator are Nis a.d. Novi Sad (Prime Listing), Metalac a.d. Gornji Milanovac (Standard Listing), AIK banka a.d. Beograd (Open Market) and Čačanska banka a.d. Čačak (Open Market).

In consistence with the non-financial performance elements and based on the regression analysis performed, even 4 performance elements have the greatest effect on the dependent variable; these are: learning, performance measurement, management and employment priorities.

Top rated companies according to this indicator are: Čačanska banka a.d. Čačak, Komercijalna banka a.d. Beograd, Metalac a.d. Gornji Milanovac and NIS a.d. Novi Sad. The analysis identified drastic discrepancies in the assessment of financial and nonfinancial performance elements in AIK banka a.d. Niš, which has remarkable results concerning the analysis of the financial report, however its quality management sector is poorly developed.

Our analysis is more focused on the position of listed companies. Namely, Nis a.d., as one of the companies with the greatest liquidity whose shares are most traded in the market and which has the Prime Listing. Although this company is characterized by outstanding financial performance elements, its non-financial performance elements are not developed. Although positioned on the Open Market, Čačanska banka a.d. holds the first place according to development of its non-financial performance elements, as well as the first four places referring to the rating of its financial performance elements.

Therefore, one can say with full confidence that there is no agreement of financial and non-financial performance elements in terms of their importance for ranking of companies on the BSE (general hypotheses $\mathrm{H}_{11}$ and $\mathrm{H}_{21}$ are confirmed). This is also supported by the testing of the hypotheses concerning the correlation analysis of the relationship between the volume of shares sold in the stock market and financial indicators and the relationship between the volume of shares sold and the non-financial indicators. Rank correlation coefficients show that there is not even moderate correlation 
between the volume of shares sold and non-financial indicators (the null hypothesis $\mathrm{H}_{60}$ is thereby confirmed). These coefficients together with their statistical significance are shown in the table below. The only exception is the following: there is strong correlation between the non-financial performance element management and the dependent variable volume of shares sold which is confirmed by the Spearman's rank correlation coefficient of $\mathrm{Rs}=0.578$ and $\mathrm{p}=0.08$. (null hypothesis $\mathrm{H}_{60}$ is confirmed)

Table 6: Spearman's rank correlation coefficient

\begin{tabular}{|c|c|c|c|}
\hline \multicolumn{4}{|c|}{ Correlations } \\
\hline & & & Number of share transaction \\
\hline \multirow{12}{*}{$\begin{array}{l}\text { Spearman's } \\
\text { rho }\end{array}$} & \multirow{3}{*}{ Management } & Correlation Coefficient & 578 \\
\hline & & Sig. (2-tailed) & 080 \\
\hline & & $\mathrm{N}$ & $\frac{, 000}{10}$ \\
\hline & \multirow{3}{*}{$\begin{array}{l}\text { Performance } \\
\text { measurement }\end{array}$} & Correlation Coefficient &,- 268 \\
\hline & & Sig. (2-tailed) &, 454 \\
\hline & & $\mathrm{N}$ & 10 \\
\hline & \multirow{3}{*}{$\begin{array}{l}\text { Priorities for } \\
\text { improving }\end{array}$} & Correlation Coefficient & 036 \\
\hline & & Sig. (2-tailed) & 922 \\
\hline & & $\mathrm{N}$ & 10 \\
\hline & \multirow{3}{*}{ Learning } & Correlation Coefficient &, 052 \\
\hline & & Sig. (2-tailed) & 886 \\
\hline & & $\mathrm{N}$ & 10 \\
\hline
\end{tabular}

As far as the financial performance elements are concerned, only the value of the Spearman's rank correlation coefficient referring to the dependent variable number of share transaction and the financial variable $R O E$ was found statistically significant. Therefore, we obtained Spearman's rank correlation coefficient of Rs $=0.533, \mathrm{p} \approx 0.05$. This coefficient indicates the existence of strong correlation, which was also confirmed by the significance level of $p=\alpha \approx 0.05$. (alternative hypothesis $\mathrm{H}_{31}$ is confirmed)

\section{Conclusion}

Based on the research conducted, analysis of the questionnaires and the results of the statistical/econometric analysis, the following can be concluded and/or suggested:

- Comparative analysis of the situation on the BSE with that on the WSE and the ZSE, respectively, brings us to the conclusion that the absence of the IPOs in the privatization of public enterprises in the Republic of Serbia led to a major collapse of the domestic capital market compared to markets of other transitional countries in the region;

- One of the biggest constraints concerning this research is the small number of surveyed companies, as well as the limitation to a single capital market. Since the comparative analysis referenced the BSE against the WSE and the ZSE, future research will include companies from these two foreign markets, i.e. the companies from the WSE and the ZSE will be selected and surveyed;

- Analysis of financial performance elements should be expanded to include a few more ratios which would make the analysis more detailed, such as ROA (return on assets) and ROS (return on sales); 
- The volume of literature on this topic is very modest and there is obvious lack of studies on the analysis of the financial indicators of public companies, given the very small number of authors in the country and abroad interested in this topic;

- The analysis included only two companies headquartered abroad, so it was not possible to conduct such comparative analysis where the companies would have been divided into two groups: the domestic and the foreign ones;

Based on the performed analysis, the following recommendations can be offered to the companies, as well as the stock exchange executives:

- The results of the analysis indicate that non-financial performance elements of the issuers are not included in listing conditions. However, the inclusion of such indicators would raise the awareness of the management of listed companies on the significance of improvement of non-financial performance elements. In addition, those companies investing in non-financial performance elements would receive additional encouragement to apply for the Prime/ Standard listing.

- Recommendations to management of AIK banka a.d. Niš, is to invest effort and resources in developing quality management system, as it will also be the investment in improving numerous financial performance elements.

- Recommendations to management of Čačanska banka a.d. Čačak is to apply for the Standard Listing as soon as possible, given that the results of the analysis conducted in this paper confirm the excellent ratings of their both financial and non-financial performance elements. It should be noted that the perspective investors would conduct almost identical analysis and arrive at the same conclusion. Thus, they would most definitely invest their money in the purchase of the bank' shares.

\section{References}

Benic, V., and I. Franic. 2008. Comparative analysis of Croatia and the countries of the region capital markets liquidity. Financial Theory and Practice 32: 481-502.

Brouch, G. 2011. Total Quality Management as a theory of change. International Journal Total Quality Management \& Excellence 39: 15-20.

Beaver, W., and S. Ryan. 2000. Biases and lags in book value and their effects on the ability of the book-to-market ratio to predict book return on equity. Journal of Accounting Research 38: 127-148.

Certo, S. T. 2003. Influencing Initial Public Offering Investors with prestige: signaling with board structures, Academy of Menagement Review 28: 432-446

Cirović, M. 2007. Financial Markets - instruments, institutions and technology. Scientific Society of Serbia: Belgrade.

Chordia, T., A. Sarkar, and A. Subrahmanyam. 2003. An Empirical Analyses of Stock and Bond Market Liquidity. Federal Reserve Bank of New York Staff Reports 164: 3-28. 
Cohen, J.W. 1988. Statistical power analysis for the behavioral sciences (2nd edn), Lawrence Erlbaum Associates: USA.

Danielson, M. and T. Dowdell. 2001. The Return-Stages Valuation Model and the Expectations within a Firm's P/B and P/E Ratios. Financial Management 30: 93-124.

Dale, B. G., T. Wiele, and J. Iwaarden. 2013. Menaging Quality, Blackwell Publishing: Oxford.

Degryse, H. 2009. Competition between financial markets in Europe: what can be expected from MiFID?. Financial Market and Portfolio Management 23: $93-$ 103.

Dugalic, V. M. Stimac. 2006. Basics of stock market operations, Stubovi kulture: Belgrade.

Domanovic, V. 2013. The effectiveness of the performance measurement in terms of contemporary business environment. Economic Horizons 15: 33-46.

Eric, D.D. 2003. Financial markets and instruments. Cigoja prints: Belgrade.

Easton, D. P. 2004. PE Ratios, PEG Ratios, and Estimating the Implied Expected Rate of Return on Equity Capital. Accounting Review 79: 73-95.

Haan, J., S. Oosterloo, and D. Schoenmaker. 2009. The European Financial Markets. Cambridge University Press: UK.

Hall, B. H., A. Jaffe, and M. Trajtenberg. 2005. Market value and patent citations, available at: http://elsa.berkeley.edu/ bhhall/papers/HallJaffeTrajtenberg _ RJEjan04.pdfv/ (accessed 10 September 2013).

Helfet, A. E. 2001. Financial Analysis Tools and Techniques. McGraw-Hill: USA.

Hoyle, D. 2009. ISO 9000 Quality Systems Handbook. Butterworth-Heinemann: UK.

Isaksson, R. 2006. Total Quality Management for Sustainable Development - process based system models. Business Process Management Journal 12: 632-645.

Jaksic, M. 2011. Financial market - instruments and institutions. Faculty of Economics, University of Kragujevac: Serbia.

Jovetic, S. 2012. Methodology of supervising and improving Maintenance process performanceS. Economic Themes, University of Nis, Faculty of Economics 3: 375-396.

Jovetic, S. 2011. Quality Management systems in the Higher Education. International Conference: Technology, Culture and Development, Tivat Montenegro: 102-113.

Mumović, S. V. Pavlović. 2010. Significance development of financial markets for Serbian economy. Industry 38: 41-67.

Malinic, D. 2009. Contemporary challenges of financial statements integrated research quality. Ekonomika 57: 138-155

Mach, A. 1998. Introduction of a joint stock company on the stock exchange. LEGE ARTIS Dom Wydawniczy, Kraków: Poland.

Oakland, J. S. 2006. Quality management in the 21 st century- implementing successful change. Int. Journal Productivity and Quality Management 1: 69-87. 
Pečaric, M., J. Arnerić, and M. Radić. 2012. Financial markets and institutions in the Republic of Croatia in the process of joining the European Union, Faculty of Economics Rijeka: Croatia.

Proniewski, M., A. Niedźwiecki. 2009. Exchange Securities in Warsaw-shot retrospective, Drukarnia Biały Kruk, Białystok: Poland.

Pallant, J. 2011. SPSS Survival Manual: A step by step guide to data analysis using SPSS, Open University Press, McGraw-Hill, Berkshire: UK.

Ramanna, K., and L. R. Watts. 2012. Evidence on the Use of Unverifiable Estimates in Required Goodwill Impairment. Review of Accounting Studies 17:749-780.

Sieradzki, R. 2013. Does it pay to invest in IPOs? Evidence from the Warsaw Stock Exchange, National Bank of Poland: Poland.

Stijin, C., S. Djankov, and D. Klingebiel. 2001. Financial Transition in Europe and Central Asia: Challenges of the New Decade. The World bank: Washington.

Suganthi, L., and A. Samuel. 2004. Total Quality Menagement, Prentice Hall of India: New Delhi.

\section{Endnotes}

1. For more information on the listing conditions please see: http://www.belex. rs/trzista_i_hartije/uslovi.

2. $E y=y x i / y_{i}^{*}=b 1 * x i / b o+b 1 x i, z a i=1,2,3 \ldots . n$

3. WIG30 is a capitalization-weighted stock market index of the thirty largest companies on theWSE

4. SETX is a capitalization-weighted index consisting of blue chip stocks traded on stock exchanges in the region of South East Europe. Currently the SETX includes stocks listed in Bucharest, Ljubljana, Sofia, Belgrade and Zagreb

5. For more information on the contents of the standard please visit: http://www. ekfak.kg.ac.rs/sites/default/files/nastava/Novi\%20Studijski\%20Programi/ III\%20godina/MenadzmentKvalitetom/ZavrsniRadovi/SRPS\%20ISO \%20 9004.pdf 